\title{
Migration of radioactive contaminants discharged into the Yenisei river by the Krasnoyarsk mining and chemical complex
}

\author{
S.M. Vakulovsky, E.G. Tertyshnik and T.S. Borodina \\ Scientific Production Association "Typhoon", Lenin Str. 82, \\ Kaluga Region, Obninsk 249020, Russia
}

\begin{abstract}
Cooling waters from three reactors have been discharged into the Yenisei since 1958. Radioactive monitoring of water and bottom sediments was based on systematic observation at stationary monitoring sites and field studies. Regular observations were carried out in the near zone of the discharge and at measuring sections 250 , 370 and $890 \mathrm{~km}$ far from the discharge point. The major contributors to water radioactive contamination were ${ }^{24} \mathrm{Na}$, ${ }^{32} \mathrm{P},{ }^{46} \mathrm{Sc},{ }^{54} \mathrm{Mn},{ }^{51} \mathrm{Cr}$ and ${ }^{65} \mathrm{Zn}$. At a distance of $15 \mathrm{~km}$ from the point of discharge of cooling waters, the concentrations of short-lived radionuclides were 10-100 times and those of long-lived radionuclides 100-1000 times lower the levels set by standards of radioactive safety. The studies of interface distribution in the river water suspended material system show that only ${ }^{24} \mathrm{Na},{ }^{51} \mathrm{Cr}$ and ${ }^{32} \mathrm{P}$ move in the liquid phase in the river water, whereas ${ }^{137} \mathrm{Cs}$ is evenly distributed between the suspended material and the liquid phase, most radionuclides moving primarily with the suspended material. Chemical forms of isotopes occurrence in water were determined.
\end{abstract}

\section{INTRODUCTION}

For more than 30 years the cooling waters of the direct-flow reactors of KMCIC (the first reactor was put into operation in 1958, the second in 1961 and the third one with the closed loop in 1964) were discharged to the Yenisei River. Both direct-flow reactors were shut down in 1992. Due to many-years discharges, the Yenisei river downstream and the adjacent flood plain have been contaminated to a varying degree, depending on a distance from the source and hydrological conditions of radioactivity removal from the water flow [1].

The contaminated part of the river is a unique testing site for investigation of radionuclides behavior in water ecosystems, intake by man through food chains, both aquatic and those associated with use of parts of the flood plain adjacent to the river, processes of removal of radionuclides from water flow. It can be used for verification of physico-mathematical models of radionuclides migration and models evaluating radioecological consequences of the radioactive contamination as well as for trying out tools and methods of monitoring of the radioactive contamination of water systems.

\section{RADIONUCLIDES DISCHARGES TO THE YENISEI}

Occurrence of radionuclides in the Yenisei is due to the following reasons:

- discharge of cooling waters of the direct-flow reactors AD and ADE-1 operating in the nominal mode;

- discharge of low-level trap water after their cleaning by the physical-chemical method;

- discharge of cooling water of working channels of the control and protection system of the power reactor ADE-2 producing heat and electric power production at a closed cooling circuit.

The first reactor $\mathrm{AD}$ designed for production of weapons-grade plutonium was put into operation in August 1958, the second ADE-1 in August 1960 and the third ADE-2 in December 1963. The reactor AD was shut down and taken out of service on 30.06 .1992 and the reactor ADE-1 on 29.09.92. The reactor ADE- 2 continues operating and produces heat and electricity for the city of Zhelesnogorsk.

Geographically, the points of wastewater discharge are located on the right bank of the Yenisei at 80 and $85 \mathrm{~km}$ from Krasnoyarsk.

The content of radionuclides in wastewater is monitored by daily sampling and further analysis in laboratory. In the first years of the reactor operation only beta-activity was measured in wastewater. At that time, no methods and logistic base were available for determination of wastewater make-up. 
In the latest 20 years, the radionuclide monitoring is carried out by the following scheme. Sampling is performed on a daily basis and wastewater make-up is identified using semi-conductor gamma spectrometer without pre-concentration; then volumetric activity of principal short-lived radionuclides ${ }^{56} \mathrm{Mn}\left(\mathrm{T}_{1 / 2}=2.6 \mathrm{~h}\right)$ and ${ }^{24} \mathrm{Na}\left(\mathrm{T}_{1 / 2}=15 \mathrm{~h}\right)$ is determined. Determination of other radionuclides in a fresh sample in the presence of ${ }^{56} \mathrm{Mn}$ and ${ }^{24} \mathrm{Na}$ was not possible. Once a week a single sample was subject to radiochemical treatment for determination of the volumetric activity of ${ }^{64} \mathrm{Cu}\left(\mathrm{T}_{1 / 2}=12.7 \mathrm{~h}\right),{ }^{31} \mathrm{Si}\left(\Gamma_{1 / 2}=\right.$ $2.62 \mathrm{~h}),{ }^{76} \mathrm{As}\left(\mathrm{T}_{1 / 2}=26.32 \mathrm{~h}\right),{ }^{131} \mathrm{I}\left(\mathrm{T}_{1 / 2}=8.01 \mathrm{~h}\right)$ and ${ }^{239} \mathrm{~Np}\left(\mathrm{~T}_{1 / 2}=2.35 \mathrm{~h}\right)$.

The volumetric activity of ${ }^{32} \mathrm{P}\left(\mathrm{T}_{1 / 2}=14.29\right.$ days) was determined in a weekly sample consisting of daily samples. Other mid- and long-lived radionuclides were determined in a monthly sample consisting of daily samples.

Tablel shows radionuclides discharges to the Yenisei in 1987-2000 (the latest 5 years before and the first 7 years after reactors were shut down).

Table 1

Radionuclides discharges into the Yenisei for 1987-2000

\begin{tabular}{|c|c|c|c|c|c|c|}
\hline \multirow[t]{2}{*}{ № } & \multirow{2}{*}{ Radionuclide } & \multirow{2}{*}{$T_{1 / 2}$} & \multirow{2}{*}{ Unit } & \multicolumn{2}{|c|}{ Average annual value } & \multirow{2}{*}{$\begin{array}{c}\text { Ratio of } \\
\text { average annual values } \\
1987-1991 / 1996-2000\end{array}$} \\
\hline & & & & $1987-1991$ & $1996-2000$ & \\
\hline 1 & ${ }^{24} \mathrm{Na}$ & $15,0 \mathrm{~h}$ & $\mathrm{TBq}$ & 11930 & 57.4 & 208 \\
\hline 2 & ${ }^{32} \mathrm{P}$ & $14,3 \mathrm{~d}$ & $\mathrm{TBq}$ & 371 & 10.4 & 36 \\
\hline 3 & ${ }^{5 T} \mathrm{Cr}$ & $27,7 \mathrm{~d}$ & $\mathrm{TBq}$ & 404 & 3.2 & 126 \\
\hline 4 & ${ }^{54} \mathrm{Mn}$ & $312 \mathrm{~d}$ & $\mathrm{GBq}$ & 2874 & 4.2 & 684 \\
\hline 5 & ${ }^{60} \mathrm{Co}$ & $5,27 \mathrm{y}$ & $\mathrm{GBq}$ & 1402 & 56.2 & 25 \\
\hline 6 & ${ }^{65} \mathrm{Zn}$ & $244 \mathrm{~d}$ & $\mathrm{GBq}$ & 3882 & 34 & 114 \\
\hline 7 & ${ }^{90} \mathrm{Sr}$ & $29,1 \mathrm{y}$ & $\mathrm{GBq}$ & 347 & 23.4 & 15 \\
\hline 8 & ${ }^{106} \mathrm{Ru}$ & $1,01 \mathrm{y}$ & $\mathrm{GBq}$ & 1695 & 7.2 & 235 \\
\hline 9 & ${ }^{134} \mathrm{Cs}$ & $2,06 y$ & $\mathrm{GBg}$ & 60.2 & 1.2 & 50 \\
\hline 10 & ${ }^{137} \mathrm{Cs}$ & $30,0 y$ & $\mathrm{GBq}$ & 713 & 43.8 & 16 \\
\hline 11 & ${ }^{152} \mathrm{Eu}$ & $13,3 \mathrm{y}$ & $\mathrm{GBq}$ & 480 & 5.0 & 96 \\
\hline
\end{tabular}

As Table 1 indicates radionuclides discharges into Yenisei reduced by 1-2 orders of magnitude for different radionuclides after shutdown of two reactors.

\section{RADIONUCLIDES CONCENTRATIONS IN THE YENISEI RIVER WATER}

Starting from 1973 SPA «Typhoon» and the external dosimetry service of the KMCIC carried out measurements of radionuclide concentrations in the Yenisei. Water samples were collected over $2000 \mathrm{~km}$ from Krasnoyarsk to Dudinka. The greatest number of samples were collected in the sites characterized by uniform distribution of radionuclides over the river cross-section. The averaged concentrations of radionuclides in river water over for a number of years in these points are summarized in Table 2.

It is to be noted that even when all three reactors were operating the radionuclides concentrations in river water near the mentioned population points were below the applicable sanitary norms by many orders of magnitude. For determination of such low levels the concentration techniques were used including separation of suspended material from water with filtration systems of large capacity, boiling down water samples of large volume and application of special-purpose selective sorbents [2].

Determination of radionuclide activity in samples resulting from water sample concentration was performed using gamma spectrometers with both home-made $\mathrm{Ge}(\mathrm{Li})$ detectors of large volume and EG\&G ORTEC (US) high-purity germanium detectors.

Using the data of Tables 2 regarding radionuclides concentrations in the distance $190 \mathrm{~km}$ in the time period when the reactor was operating, transport of some radionuclides through the river cross section in this location can be estimated. Results of calculations are listed in Table 3, the water discharge assumed to be $2930 \mathrm{~m}^{3} / \mathrm{s}$ at the sampling time. 
Table 2

Averaged concentrations of radionuclides in the Yenisei water for $1973-1993, \mathrm{mBq} / \mathrm{I}$

\begin{tabular}{|c|c|c|c|c|c|c|}
\hline Radionuclide & $\begin{array}{l}\text { Distance from the source } \\
(\mathrm{km})\end{array}$ & 1973 & $\begin{array}{l}1985-1991 \\
\text { (average) }\end{array}$ & $\overline{1992}$ & 1993 & 2000 \\
\hline${ }^{37} \mathrm{Cs}$ & $\begin{array}{l}0-5 \\
190 \\
240 \\
800 \\
1345\end{array}$ & $\begin{array}{l}148 \\
- \\
330 \\
295\end{array}$ & $\begin{array}{l}- \\
6 \\
5 \\
5\end{array}$ & $\begin{array}{l}- \\
2 \\
6 \\
2\end{array}$ & $\begin{array}{l}- \\
1 \\
2 \\
2\end{array}$ & $\begin{array}{c}2,3 \\
1.3 \\
0.9 \\
-\end{array}$ \\
\hline${ }^{5} \mathrm{Cr}$ & $\begin{array}{c}0-5 \\
240 \\
800 \\
1345 \\
\end{array}$ & $\begin{array}{c}15000 \\
- \\
330 \\
150 \\
\end{array}$ & $\begin{array}{c}- \\
1900 \\
1100 \\
700 \\
\end{array}$ & $\begin{array}{l}700 \\
150 \\
160 \\
\end{array}$ & & $\begin{array}{c}380 \\
14\end{array}$ \\
\hline${ }^{58} \mathrm{Co}$ & $\begin{array}{c}240 \\
800 \\
1345 \\
\end{array}$ & $\begin{array}{c}318 \\
- \\
- \\
\end{array}$ & $\begin{array}{c}26 \\
12 \\
7 \\
\end{array}$ & $\begin{array}{c}4 \\
- \\
10 \\
\end{array}$ & & \\
\hline${ }^{60} \mathrm{Co}$ & $\begin{array}{c}0-5 \\
240 \\
800 \\
1345 \\
\end{array}$ & $\begin{array}{c}318 \\
- \\
- \\
- \\
\end{array}$ & $\begin{array}{l}- \\
7 \\
4 \\
4\end{array}$ & $\begin{array}{l}- \\
- \\
8 \\
-\end{array}$ & & 4.7 \\
\hline${ }^{46} \mathrm{Sc}$ & $\begin{array}{c}240 \\
800 \\
1345\end{array}$ & & $\begin{array}{c}11 \\
5 \\
5\end{array}$ & & & \\
\hline${ }^{54} \mathrm{Mn}$ & $\begin{array}{c}0-5 \\
240 \\
800 \\
1345\end{array}$ & $\begin{array}{c}85 \\
- \\
- \\
- \\
\end{array}$ & $\begin{array}{l}- \\
8 \\
3 \\
3\end{array}$ & & & \\
\hline${ }^{90} \mathrm{Sr}$ & $\begin{array}{l}0-5 \\
190\end{array}$ & - & - & & & $\begin{array}{l}3,2 \\
2,5\end{array}$ \\
\hline${ }^{65} \mathrm{Zn}$ & $\begin{array}{c}0-5 \\
240 \\
800 \\
1345\end{array}$ & $\begin{array}{c}740 \\
- \\
35 \\
24\end{array}$ & $\begin{array}{c}- \\
23 \\
- \\
-\end{array}$ & & & \\
\hline
\end{tabular}

Table 3.

Transport of ${ }^{137} \mathrm{Cs}$ and ${ }^{90} \mathrm{Sr}$ in the Yenisei in 2000 for the distance $190 \mathrm{~km}$ from the source

\begin{tabular}{|c|c|c|c|c|}
\hline Radionuclide & $\begin{array}{c}\text { Bulk concentration, } \\
\mathrm{Bq} / \mathrm{m}^{3}\end{array}$ & $\begin{array}{c}\text { Transport, } \\
\text { GBq/year }\end{array}$ & $\begin{array}{c}\text { Discharge, } \\
\text { GBq/year }\end{array}$ & $\begin{array}{c}\text { Ratio } \\
\text { transport/discharge }\end{array}$ \\
\hline${ }^{137} \mathrm{Cs}$ & 1.3 & 120 & 30 & 4 \\
\hline${ }^{90} \mathrm{Sr}$ & 2.5 & 230 & 22 & 10 \\
\hline
\end{tabular}

As Tables 3 indicates, the major part of ${ }^{90} \mathrm{Sr}$ transported by the Yenisei in the distance $190 \mathrm{~km}$ from the source is due to global contamination of river water. A portion of transported ${ }^{137} \mathrm{Cs}$ can be associated with the wash-out of «old» radiocesium from the river channel.

In the course of the expedition carried out in August 1973 an attempt was made to determine the chemical forms, in which isotopes enter the river, and the portion of isotopes transported on solid particles of different sizes. A sample of water entering the industrial complex, a sample of discharged wastewater and a sample of water from the river were taken. The latter sampling site was several kilometers downstream from the site of waste discharges from the industrial complex to the river. To separate solid particles suspended in water and to determine their sizes, the water from the river (sample IWI) was passed through a series of copper sieves with different mesh sizes. A set of sieves with mesh sizes of $280 \mu \mathrm{m}, 180 \mu \mathrm{m}, 80 \mu \mathrm{m}$ and $40 \mu \mathrm{m}$ was used.

To separate smaller suspended particles these water samples were filtered through a layer of filter paper and layer of cotton wool. Then the filtered water was passed through three ion-exchange columns connected in series. The first column was filled with ferrocyanide, the second column contained a cation 
exchange resin (in $\mathrm{H}^{+}$form) of the $\mathrm{KY}-2$ grade, and the third column contained an anion exchange resin (in $\mathrm{OH}^{-}$form) of the ЭДЭ-10П grade. Such a combination of ferrocyanide and ion exchange resins makes it possible to remove radioactive components from the water more fully and at the same time to determine the forms of their occurrence in the water. The wastewater sample $(1 \mathrm{WW})$ was filtered through a double layer of filter paper and cotton wool, and then passed through the columns with ferrocyanide and ion. exchange resins. The water samples taken for studying the chemical forms of isotopes were analyzed by fractions using a gamma spectrometer with a semiconductor detector. Table 4 presents the content of isotopes in individual fractions (in relative units). In our calculations, the total activity of each isotope contained in all fractions (suspended particles, anionite, cationite and ferrocyanide) was taken to be 100\% the content of isotopes in the water entering the industrial complex (sample 1WI) was found to be lower than the sensitivity threshold for most fractions. Only suspended particles separated from this sample contained insignificant amounts of ${ }^{51} \mathrm{Cr},{ }^{54} \mathrm{Mn},{ }^{66} \mathrm{Zn}$ and ${ }^{60} \mathrm{Co}$.

Table 4

The relative content of isotopes in different fractions, $\%$

\begin{tabular}{|c|c|c|c|c|c|c|c|c|c|c|c|c|c|c|c|}
\hline Sample & ${ }^{134} \mathrm{Cs}$ & ${ }^{137} \mathrm{Cs}$ & ${ }^{65} \mathrm{Zn}$ & ${ }^{54} \mathrm{Mn}$ & ${ }^{58} \mathrm{Co}$ & ${ }^{60} \mathrm{Co}$ & ${ }^{59} \mathrm{Fe}$ & ${ }^{144} \mathrm{Ce}$ & ${ }^{141} \mathrm{Ce}$ & ${ }^{152} \mathrm{Eu}$ & ${ }^{154} \mathrm{Eu}$ & ${ }^{95} \mathrm{Zr}+$ & ${ }^{46} \mathrm{Sc}$ & ${ }^{51} \mathrm{Cr}$ & Fraction \\
\hline $1 \mathrm{WW}$ & 47 & 67 & 50 & 40 & 44 & 83 & 91 & 41 & 58 & 94 & 94 & 55 & 89 & 38 & Suspended particles \\
\hline $1 W W$ & 52 & 33 & 43 & 8 & 35 & 11 & 3 & 12 & 14 & 0.0 & - & 18 & - & 2 & Ferrocyanide \\
\hline IWW & - & - & 7 & 52 & 19 & 5 & 2 & 33 & 28 & 0.0 & 6 & - & 4 & 2 & Cationite \\
\hline $1 \mathrm{WW}$ & 1 & - & - & - & 1 & 1 & 3 & 14 & - & 0.0 & - & 27 & 7 & 58 & Anionite \\
\hline 1RW & 37 & - & 31 & 33 & 35 & 37 & 39 & 38 & 61 & 40 & - & 100 & 34 & 17 & $\begin{array}{c}\text { Suspended particles } \\
40-80 \mu \mathrm{m}\end{array}$ \\
\hline IRW & - & - & 9 & 2 & 3 & 2 & 61 & - & - & 4 & - & - & 5 & - & $\begin{array}{c}\text { Suspended particles } \\
80-180 \mu \mathrm{m}\end{array}$ \\
\hline IRW & 11 & - & 22 & 15 & 19 & 19 & - & 17 & - & 17 & - & - & 21 & 6 & $\begin{array}{c}\text { Suspended particles } \\
180-280 \mu \mathrm{m}\end{array}$ \\
\hline IRW & 52 & - & 38 & 50 & 43 & 41 & - & 44 & 39 & 39 & - & - & 40 & 2 & $\begin{array}{c}\text { Suspended particles } \\
>280 \mu \mathrm{m}\end{array}$ \\
\hline IRW & - & - & - & - & - & - & - & - & - & - & - & - & - & 75 & Anionite \\
\hline
\end{tabular}

The results of investigations presented in Table 4 indicate that the portion of radionuclides sorbed on suspended particles in the discharged water ranged from $40 \%$ to $90 \%$. Significant amounts of ${ }^{144} \mathrm{Ce}$, ${ }^{95} \mathrm{Zr}+{ }^{95} \mathrm{Nb}$ and ${ }^{51} \mathrm{Cr}$ in anionic form were observed. The distribution of radionuclides sorbed on suspended particles in the water near the site of discharges by the sizes of these particles was characterized, as a rule, by two maximums. Particles of the least size $(40-80 \mu \mathrm{m})$ and of the largest size $(280 \mu \mathrm{m})$ turned out to be the highly contaminated.

\section{Acknowledgments}

This research is supported by the ISTC Project \#1404.

\section{References}

[1] S.M.Vakulovsky et. al. «Radioactive contamination of the Yenisei River». Journal of Environmental Radioactivity, v.29, N3, 1995, pp.225-236.

[2] S.M.Vakulovsky et. al. "Estimation of the impact of the Krasnoyarsk Mining and Chemical Industrial Complex on the radioecological condition of the Yenisei river". Izvestia vuzov. Nuclear energy., No 2-3, 1994, pp.124-130. 